Matthew James Suriano*

\title{
The Historicality of the King: An Exercise in Reading Royal Inscriptions from the Ancient Levant
}

\begin{abstract}
The problem with using royal inscriptions as historical sources is their inherent bias. The interests of the king drive the narratives of royal inscriptions. Yet this essential feature reveals their underlying concept of history. In royal inscriptions, historical thought is defined by the life and experience of the king. This article will present a hermeneutic for reading royal inscriptions that focuses on the individual king. The article will first look at the concept of historical time in epigraphic Hebrew and Old Aramaic sources before examining the complicated ways in which this concept is rendered in the principal genres of royal writings, the memorial and the dedicatory inscription. A survey of features found in memorial inscriptions from Dibon (the Mesha Stele) and Sam'al (Kulamuwa), followed by a study of the Old Byblian dedicatory inscriptions, will explore the complex process of configuring time and narrative around the king. In each genre of royal inscription, the linear time of the ruler intersects with cyclical traditions of kingship, revealing the historicality of respective king.
\end{abstract}

Keywords: royal inscriptions, Mesha Stele, Zincirli/Sam'al, Byblos

DOI 10.1515/janeh-2014-0003

The thing to do should be to view the document not as a "source of information," but as information in itself; not as an opening on a reality laying beyond, but as an element which makes up that reality. - Mario Liverani (1973: 179)

The concerns for personal identity and self-justification lie at the heart of many historiographic documents... in most cases, these concerns involve the person of the king - his right to rule or his giving of an account of political actions before gods and men. Yet unless we are to assume that the king was universally recognized as the embodiment of the state, we cannot speak of such texts as history. - John Van Seters (1983: 2)

*Corresponding author: Matthew James Suriano, The Joseph and Rebecca Meyerhoff Center for Jewish Studies, University of Maryland, 4130 Susquehanna Hall, College Park, MD 20742, USA, E-mail: msuriano@umd.edu 
Since its discovery in 1868, scholars have debated the historical value of the Mesha Stele (KAI 181; Dearman 1989; Lemaire 2007; Na'aman 2007: 145-83; Grabbe 2007: 144-46). While it provides a seeming parallel to the events told in 2 Kings 3, from a Moabite point of view, the stele offers no precise chronological data beyond references to the Moabite king's "days.” In fact, the stele is a classic example of a memorial inscription (Miller 1974: 12-18), in which a king narrates his own history. As such, royal inscriptions like the Mesha Stele are overtly biased; they reflect the self-interest of the king, and this self-interest governs their selection and manipulation of information. But given their essential nature, how should royal inscriptions be interpreted? Do texts, such as the Mesha Stele, ${ }^{1}$ actually lack a sense of chronology? More importantly, what is their underlying sense of history? In order to answer these questions, it is necessary to take the royal inscription's most defining literary feature, the centrality of the king, and examine it as an aspect of historical thought.

As John Van Seters stated in 1983, the singular interests of the king predicated the narratives found in royal inscriptions, rather than the antiquarian interests of a larger cultural collective. Nevertheless, Van Seters's observation (1983: 2-6) was only meant to limit such texts from broader discussions of history writing. Yet, a decade earlier, Mario Liverani (1973: 178-82) had argued that the mimesis of royal inscriptions represented their primary historical value. Liverani's idea offers a much more productive approach to royal inscriptions than that of Van Seters, who impeached not just the message but in fact the medium of royal inscriptions. But if the medium is the message, to use Marshall McLuhan's famous phrase, what is the underlying concept of history in royal inscriptions? An examination of selected royal inscriptions, representing different genre, will suggest that their concept of history was rendered through the configuration of time and narrative around the king.

Instead of reading the inscriptions as more or less verifiable informants of the past, we should see these texts as products of the past. That is, their shape and form, in fact their genre, offer important insight into their underlying concepts of history. ${ }^{2}$ As a biblical scholar and form critic, Van Seters was attentive to genre (1983: 191-95), and his own work followed J. Maxwell Miller's seminal study of memorial inscriptions (1974). But for Van Seters, the exercise was merely done to

1 Memorial inscriptions, as opposed to putative "victory inscriptions," are historically retrospective (Miller 1974: 9-18). Yet the nature of their internal chronologies is typically overlooked. 2 Although there are many examples of mixed genre inscriptions (Parker 1999), this essay will treat dedicatory and memorial inscriptions as discreet categories in order to establish a constructive heuristic starting point. Likewise, this essay will deal exclusively with alphabetic inscriptions in Northwest Semitic, although hieroglyphic Luwian sources also represent an important corpus of royal inscriptions from the Levant. 
determine if the various genres of royal inscriptions conformed to his definition of historical writing (which they failed to do). ${ }^{3}$ In fact, the principal genres of Northwest Semitic inscriptions, memorial and dedicatory, do not conform to modern concepts of history. Again, the reasons are due to the role of the king within the text. But this centrality actually reveals a notion of time that plays a crucial part in the composition of royal writings. In ancient societies, time was often ordered around the reign of kings. ${ }^{4}$ This temporal concept, which will be called the historical time of the king, is operative in sources that counted years according to the king's reign or labeled years after major events of his reign. But the king-centered inclination of royal inscriptions also reveals a broader idea of kingship that existed in history. Kingship was a metahistorical category; it was a cyclical institution that reoccurred with each new ruler. Conversely, each new ruler reused common (historical) motifs of kingship in order to validate their rule. The purpose of this essay is to develop a hermeneutic for reading royal inscriptions that takes into account the conflation of these two concepts of time. A survey of texts from the Levant, all dated to the Iron Age II, will show that the idea of history in royal inscriptions was centered around the respective king, formed at the intersection of the king's time with the cycle of kingship.

Historical time is a concept that extends beyond the counting of the king's years. It is evident also in the personal retrospectives offered in memorial inscriptions, such as the Mesha Stele. Altogether, the historical time of a king is subjectively rendered around the life and experience of the ruler, producing a temporal conception that is linear and event driven. Douglas Green, in his important monograph on royal inscriptions, calls this "narrative time" and describes it as the king's interpretation of historical time (2010: 120-23). Yet the process here should be reversed, as historical time is something that royal inscriptions interpret through narrative (as well as other literary means). ${ }^{5}$

3 Van Seters appropriated a quote from Johann Huizinga as his working definition of history, "an intellectual form in which a civilization renders account to itself of its past," despite Huizinga's actual intentions (Younger 1990: 26-27; Grabbe 2004: 9-10). Thus, the foundation of Van Seters's work is his own anachronistic understanding of "history writing" in the ancient world.

4 Of course, this represents one level of society. Agrarian communities, on the other hand, could measure time according to agricultural seasons (such as in the Gezer Calendar, KAI 182), or through other means.

5 The emphasis here is on interpretation, and the issue is one of historiography. This, of course, touches upon much larger questions of how to define "history," which go beyond the essay's scope. The critique, however, should not detract from the importance of superfluous Green's monograph. The primary concern of his work was not historical thought, but the elucidation of thematic elements (conquest and building) within the narrative history of royal inscriptions. 
Indeed, the process is quite complicated and involves the interaction of different temporal orders, what Paul Ricoeur would call "cosmological time" and "phenomenological time.” These orders will be defined below, but roughly speaking they stand for natural time and human experience. The metahistory of kingship, on the other hand, is not primarily formed through temporal concepts, but is established in cultural ideals of leadership and aggregate traditions of kings. ${ }^{6}$ Although kingship is cyclical, its history unfolds across royal genealogies and king lists. ${ }^{7}$ Likewise, the common tropes of conquest and building, found in royal inscriptions, relates the performance of kingship to wider historical categories. Iconography, monumental building projects, and literary production were some of the ways a ruler would enact kingship, ${ }^{8}$ replicating metaphors and symbols of power that existed in a broader historical spectrum. Therefore, if the idea of history in a royal inscription is directly tied to the king, the question should be how the king relates to the larger metahistory of kingship.

In order to answer this question, this essay will look at the two main genres of royal inscriptions, memorial and dedicatory, taking examples from Dibon, Sam'al, and Byblos. The subtle nuances and intrinsic features of these inscriptions will be explained using the theoretical terms "horizon of expectation" and "historicality." In the ancient Levant, kings would participate in the metahistory of kingship through the use of established genres. Indeed, their choice of genres, and their inclusion or exclusion of different literary motifs, all bear witness to each king's history. The framework for this activity will be called the "horizon of expectation." The term was first introduced by the literary theorist Hans Robert Jauss (1970) and was later developed by the modern historian Reinhart Koselleck in his work on hermeneutics (1985: 255-70, 1989: 649-66). ${ }^{9}$ In monumental inscriptions, moreover, the intersection of historical time with kingship's metahistorical horizon reveals the historicality of the king. Borrowed from philosophy (Heidegger 1962: §§ 19-21; Gadamer 1975: 235-75), "historicality” is used here to

\footnotetext{
6 The term "metahistory" is inspired by Hayden White (1973: 1-80), although it does not follow the specifics details of his work. His theoretical model was dependent upon western tropes, most notably in his "mode of emplotment," which followed four archetypal story forms: "Romance, Tragedy, Comedy, and Satire" (White 1973: 7-11). Instead, the metahistory of kingship will be defined here culturally, in accordance with Near Eastern sources.

7 The Sumerian King List is a famous Mesopotamian example of a metahistorical perspective on kingship (Michalowski 1983: 237-48).

8 Bruce Routledge (2004:154-55), in his study of Moabite kingship, refers to these as "kingly things."

9 Koselleck's Erwartungshorizont ("horizon of expectation") is counterpart to his Erfahrungsraum ("space of experience"), which roughly corresponds to the concept of "historical time" deployed throughout this essay.
} 
describe the historical awareness of the king as represented in his inscriptions. In memorial inscriptions, the king's historical time is described through his firstperson narrative, while in dedicatory inscriptions the king is situated within wider (third person) metahistorical narratives of kingship. In each genre of royal inscriptions, the theoretical concepts of historical time, metahistory, and historicality reveal the complexities of historical thought, organized around time and narrative, and structured according to the life and experience of the king.

\section{The idea of history in royal writings}

It is instructive to begin with three examples that are neither dedicatory nor memorial (or even monumental). These sources, which belong to Hazael of Aram-Damascus and an unnamed Israelite king (probably Jeroboam II), are brief but contain chronological data that can be related to the wider conception of time productive in royal inscriptions.

A. "That which was given by Hadad to our lord Hazael from 'Unqi in the year that our lord crossed the river."

B. "In the ninth year [of the King], from Hașerot to Gaddiyaw, a jar of washed oil."

C. "In year 15 [of the King], from Abi'ezer, to Asa' [son of] Ahimelek, Ba'ala of Elmattan.”

The first example (A) is an Aramaic text found inscribed on different objects (the so-called booty inscriptions of Hazael), ${ }^{10}$ which date to the second-half of the ninth century BCE. ${ }^{11}$ Here historical time is event driven and marked by the occurrence of the King of Aram-Damascus marching his army across the

10 The text is inscribed on two artifacts (bronze equestrian-tack) found at the Heraion in Samos and the Temple of Eretria in Euboea (Hafthorsson 2006: 43-49). For the text's historical and cultural significance, see work of Herbert Niehr (2011: 349-50). The translation here follows the treatment of Israel Eph'al and Joseph Naveh (1989: 192-200; cf. Bron and Lemaire 1989: 35-44). 11 The language and script of the texts, as well as their content, belong to the ninth century BCE (Eph'al and Naveh 1989: 192-200). The blinker from Eretria does not come from a datable context, it was discovered in the early-twentieth century. Later excavations, however, uncovered a similar blinker belonging to an eighth century stratum (Charbonnet 1986: 140-44). The second inscription is on a trapezoid-shaped frontlet and was excavated in a sixth century BCE stratum at Samos (Kyrieleis and Röllig 1988: 37-75). 
Orontes. ${ }^{12}$ The event, however, is used to reference booty, divinely attributed, and inscribed upon objects that were possibly tribute from 'Unqi. ${ }^{13}$

The second and third examples (B and $\mathbf{C}$ ) are temporary shipping records written on ostraca that were found in the royal acropolis of Samaria (Reisner, Fisher, and Lyon 1924: 114-17; Kaufman 1966). ${ }^{14}$ The ostraca belong to the first quarter of the eighth century BCE (Kaufman 1982: 229-39), ${ }^{15}$ yet they cannot be dated more precisely because their reference point is a king (or kings) who is otherwise unnamed in the text. ${ }^{16}$ Nevertheless, the dating system is configured around the king's reign and implies necessarily a starting point, ${ }^{17}$ which was probably the year that he ascended the throne (following the Israelite system of postdating). ${ }^{18}$

The counting of years in the Samaria Ostraca ultimately refers back to what the semiotician and structural linguist Émile Benveniste (1965) would call the "axial moment" of the scribe's chronology: the beginning of the Israelite king's reign. The axial moment represented the starting point of a new era, "initiating" a linear sequence through the "directing" and "measuring" of time from this moment (using Benveniste's terms). This sequence was termed "chronic time,"

12 The river (nhr) referred to here could also be the Euphrates (Eph'al and Naveh 1989: $195 \mathrm{n}$. 15; Bron and Lemaire 1989: 40; Dion 1997: 201-02). The mention of 'Unqi, however, makes the Orontes more geographically favorable (Lipiński 2000; Niehr 2011: 349 n. 55).

13 The bronze frontlet from Samos has a parallel found at Tell Tayinat, which was Kunalua, the capital of 'Unqi (Harrison 2001: 120-21; citing Kantor 1962). This parallel strongly suggests that the geographical name ' $m q$ refers to 'Unqi rather than another area.

14 For full editions of the Samaria Ostraca, see Ivan T. Kaufman's 1966 Harvard dissertation, and subsequent treatments (Lemaire 1977: 28-38; Dobbs-Allsopp et al. 2004: 339-89).

15 For this historical and cultural background see Anson Rainey (1979: 91-94), David Schloen (2001), and Hermann Niemann (2008). The ostraca record the shipment of prestige goods (Suriano 2007a; Nam 2012), wine and olive oil, from the villages surrounding the Israelite royal capital.

16 The ostraca were found in a secondary fill, which provides a terminus ad quem of the mideighth century. Their general date to the first quarter of that century can be established archaeologically (Tappy 2001: 496-503), through paleography (Kaufman 1982: 233-34 and Rollston 2010: 67), and according to their content. Historically, most scholars assign these texts to the reign of Jeroboam II (Kaufman 1966: 132-34; Schloen 2001: 159).

17 The system of enumerating years differs slightly in both ostraca, as the year name is written with an ordinal number in $\mathbf{B}$, while $\mathbf{C}$ uses a hieratic number. The ordinal numbers include the ninth and tenth years, but the hieratic are almost exclusively "Year 15" (with one indecipherable exception). These multiple dating systems are curious and have yet to be explained.

18 The system of postdating counts the king's first year following his accession (Tadmor 1979; Galil 1996; Cogan 2001: 102). That is, the year during which the king came to the throne (his accession year) was not counted, i.e., antedating. Instead, the first full calendar year marked the king's "year one." 
and alongside Benveniste's "physical time" (which he only defined loosely) it formed his two temporal orders. Paul Ricoeur reworked this two-order system into his categories of "cosmological" and "phenomenological" time, where the second represented human experience (Ricoeur 1980: 170-78). ${ }^{19}$ The first (cosmological) roughly corresponded to physical time, and its overlap with human systems of chronology (however termed) resulted in the socialization of time through calendars (Ricoeur 19843: 106-07). Thus, the enumeration of the Israelite king's reign was done according to an established calendar (objective time) with its annual beginning each autumn (Tadmor 1979; Galil 1996: 9).

The inextricable relationship of objective and subjective temporal forms, calendars versus historical time, is evident in these short examples. The subjectivity of Hazael's inscriptions is clear in its effective representation of his sovereignty (inscribed upon booty), which was set within a historical framework defined by his military achievements. ${ }^{20}$ The interrelationship of time in the Samaria Ostraca is more quotidian, but still instructive. In this example, the king's years were quantified according to a system that tracked the new moon. ${ }^{21}$ That is, the Israelite scribe accessed the objective time of the lunar calendar in order to number each year according to the king's term of office. In fact, the alternating systems of postdating versus antedating represented an important aspect of scribal agency in deciding when the historical time of the king was to begin. ${ }^{22}$ The construction of time in these sources offers insight into the rendering of historical time through narrative, as seen in both memorial and dedicatory inscriptions.

\section{Memorial inscriptions}

The most extensive type of inscription found in Northwest Semitic alphabeticwriting is the memorial text. In this type of inscription, the king's central role is

19 Ricoeur continued to develop and expand on his theory of temporal conception, initially following Benveniste's description of "chronic time" (1984: 106-07), before reworking it into "third-order time" in order to explain better the dialectical relationship between history and memory (2004: 153-55), see note 29.

20 This system of dating is also seen in one of the Arslan Tash inscriptions, KAI 232, which is fragmentary but reads: "... of our lord, Hazael in the year..." The system of naming years is probably commemorative in function but could easily coexist with conventional dating systems (Harrak 1992: 68-75; Lemaire 1998: 62 n. 38).

21 The importance of counting months for royal administrative practices is clear from both the Arad Letters and the biblical Book of Kings (Lemaire 1998: 55-58; Sanders 2008: 100-02).

22 Likewise, the decision of which calendar to use (spring versus fall) was a cultural choice. 
clear and present, beginning with the opening line: "I am Mesha, son of Chemosh-yat, king of Moab" (KAI 181:1). The memorial inscription begins with the first-person pronoun ' $n k$, which identifies the king as the speaker of the proceeding text (Miller 1974: 9-10; Drinkard 1989; Sanders 2008: 99). The narrative that follows, again in first-person, describes the events of the king's reign, detailing his military endeavors, building projects, and social reforms. Following this narrative, the memorial inscription typically concludes with a host of curses that warn against effacing the text (and neglecting the memory of the king). Although this genre is predominantly found in the Iron Age, ${ }^{23}$ its basic form appears already in the Late Bronze Age inscription of Idrimi from Alalakh and continues into the Persian Period with the Yehaumilk Stele from Byblos (fifth century BCE). ${ }^{24}$ Within this form, the concept of time that is seen in the Samaria Ostraca and Hazael's booty inscriptions is essential to the inscription's historical purview. A review of the Mesha Stele and another notable ninthcentury text, the Kulamuwa inscription (KAI 24), will show that the conceptualization of time and narrative around the king becomes much more complicated when interpreted through the genre of the memorial inscription.

The basic feature in memorial inscriptions is the king's speech, and it is this feature that defines historical thought within the text. For Benveniste (1965: 3), the speaking individual (the Ego) subjectively structures time through discourse. In linguistic terms, tense and aspect mimic the qualities of physical time, they represent the speaker's temporal perception. Language becomes the vehicle through which one establishes their "present" setting in discourse. This setting, the speaker's present, becomes the platform for defining the future and the past (Benveniste 1965: 6-7). Thus, time is subjectively rendered around the speaker. Moreover, this temporal subjectivity provides key insight into a well-known

23 A notable example is the monumental gate inscriptions of Azatiwadda at Karatepe (KAI 26; Gibson 1982; Röllig 1999: 50-81), which was written in Phoenician and hieroglyphic Luwian (Çambel 1999; Payne 2012: 20-41). The so-called Hadad Stele (KAI 214), an eighth century BCE text from Sam'al, was the memorial inscription of Panamuwa II, although it also served a dedicatory purpose (Drinkard 1989: 139). More peculiar is the early-eighth century Zakir inscription (KAI 202), which combines both dedicatory and memorial forms, effectively "[killing] two birds with one stone" (Miller 1974: 12).

24 Certainly, similar literary types are seen in other cuneiform traditions (Sumerian, Akkadian, and Hittite), but the memorial inscription is hardly derivative as Van Seters wrongly suggests (1983: 191). In fact the peculiarities in the language of the Idrimi statue, written in peripheral Akkadian, suggest that the memorial form was local to the Levant and Northwest Semitic cultures (Greenstein and Marcus 1976: 68-69). Note, however, that this literary form is absent in Ugaritic texts (Sanders 2008: 99). 
historiographical motif found in memorial inscriptions that can be called: "denigrating the past." ${ }^{25}$ The Mesha Stele provides a salient example, ${ }^{26}$

\begin{abstract}
Omri was king of Israel, and he oppressed Moab many days because Chemosh was angry with his land. And [Omri's] son succeeded him, and he also said, "I shall oppress Moab." In my days he said this, but I looked upon him and his house, and Israel is utterly destroyed forever. Omri had taken possession of the land of Madeba, and he dwelled in it his days and half the days of his son, forty years; but Chemosh restored it in my days. KAI 181:4b-9a
\end{abstract}

The perspective of time is configured around Mesha's reign and is expressed through literary means in such phrases as "in my days" (Miller 1974: 15; Drinkard 1989; Routledge 2004: 156-57). The number "forty" is also used in reference to the period of Israelite oppression. The number symbolizes a generation, and in its literary application it reveals a genealogical concept of history. Israelite hegemony is defined according to the reign of Omri and his son (Green 2010: 111); therefore the transitional events for which the Moabite ruler claims credit (over-and-against the Israelite rulers) are described according to the process of dynastic succession. ${ }^{27}$ But within this transgenerational framework, Mesha's narrative of the past implies that his father's reign was deficient. Although startling at first, this literary convention is not uncommon. In fact, it was politically expedient for kings to portray themselves in better terms than their predecessors, and an extreme example is seen in the Kulamuwa inscription (KAI 24; discussed below). Thus, a king would disparage his predecessors, despite the fact that kingship was ideally inherited (Ishida 1977: 18-25), and regardless of the political value in claiming one's place within a lineage of past kings and royal ancestors (Suriano 2009: 17-20). While the Moabite ruler could

25 Although not necessarily discussed using these terms ("denigration of the past"), the motif is commonly described in the studies of memorial inscriptions (Miller 1974: 14-16); specifically the Mesha Stele (Miller 1989: 37: Green 2010: 120-21), the Kulamuwa memorial inscription (Fales 1979), and its possible reading in the fragmentary Tel Dan Stele (Na'aman 2000; Suriano 2007b: 172).

26 All translations are by the author, and with the exceptions of the Samaria Ostraca and the Hazael booty inscriptions, all texts are numbered according to H. Donner, and W. Röllig's Kanaanäische und aramäische Inschriften (1966-1969 [ = KAI]).

27 This historical framework is clearly established in lines 2-3 with respect to Mesha (Parker 2000: 370-71), through the use of the temporal adverb 'hr (“... after my father”). But it is also coordinated with the Israelite oppressors in lines 5-6 through the form wyhlph. The verbal form is the prefix-preterit narrative conjunction with pronominal suffix; "and he succeeded him" (where 3rd m. sg. referent is Ahab and the pronominal suffix is his father Omri). Simon Parker (2000: 372) had compared this form with the narrative descriptions of Israelite succession, although he conflated different forms of record keeping in his example (1 Kg 16:23a $\beta$, 28b). 
claim kingship through his father, by whose name he first identifies himself ("Mesha the son of Chemosh-yat"), it was still necessary for him to depreciate his father's historical time in order to assert his own. ${ }^{28}$

The historiographical motif of "denigrating the past" in memorial inscriptions is about constructing a timeline of "negative past" > "positive present" > "stable future" (Fales 1979; Routledge 2004: 157-58). Following Benveniste's model, the king is the memorial inscription's Ego. As the speaker, he establishes the present situation of the narrative, and from this position he creates perspectives of both the past and the future. These perspectives are organized into generations, when expanded into the king's past as well as his future. The king's father and his ancestors reflect the past, while his sons and successors represent the future. For Ricoeur $(1980,1984,2004)$, narrative perspectives are rooted in the human experience of time and could be measured according to the natural, biological patterns of life-and-death. ${ }^{29}$ This general form of quantifying time allows for the categorization of history into generations, with a historical actor who engages perspectives that are anterior on the one side (his/her past), while also expressing a concern for posterity (Ricoeur 2004; 394-95). The final example, a ninth century BCE memorial inscription of Kulamuwa, King of Sam'al, demonstrates how this temporal subjectivity could be uniquely rendered along transgenerational lines.

I am Kulamuwa, the son of Hayya. Gabbar ruled over Y'DY, but he did nothing; then Bamah $^{(!)}$, but he did nothing. And then my father Hayya, but he did nothing. And then my brother Ša'il, but he did nothing. But I am Kulamuwa, son of TML - what I did, (my) predecessors had not done...

I am Kulamuwa, the son of Hayya. I sat upon the throne of my father... Now, whoever of my sons sits in my place and damages this inscription - may the MŠKBM not honor the

28 There is, of course, a theological dimension to Mesha's history, but again it is tied to generations. For example, Chemosh's anger with the land during the reign of Chemosh-yat becomes abated during Mesha's reign. For Green (2010: 110-111), the narrative is centered upon both Mesha and Chemosh. The role of the Moabite god, however, is ancillary to the actions and events that are driven by the Moabite king. In fact, Chemosh's role in this inscription is better described as a conferring authority, and is comparable to the role of Assyrian kings in the inscriptions from Sam'al (KAI 215, 216) and elsewhere.

29 Ricoeur's thoughts on temporality were developed in his later writings. Initially, he worked with the broad categories of cosmological and phenomenological time (1980). He later refined his discussion, and focused on chronicle time (following Benveniste; see Ricoeur 1984). The chronicle subdivisions of socialized time established a fixed point for historical perspective. Ricoeur (19843: 106) termed this the "two directions," although he later called this the anteriority and posterity of historical discourse (Ricoeur 2004: 153-54). What he first called "chronicle time," defined in relation to calendar, Ricoeur latter called "third-order time" in order to identify the historiographical processes involved in the dialectic of memory and history. 
B'RRM and may the B'RRM not honor the MŠKBM. And whoever smashes this inscription, may Ba'al Șemed, (the god) of Bamah, and Rakib-El, the lord of the dynasty, smash his head. KAI 24: 1-5a, 9a, 13b-16

The inscription, written in Phoenician, is divided into two sections that both begin with in the standard memorial fashion, "I am Kulamuwa" (Gibson 1982; Tropper 1993: 28). ${ }^{30}$ The second section describes Kulamuwa's social reforms in terms that continue to defy interpretation (see Schmitz 2013: 68-83). ${ }^{31}$ The first section offers a chronicle-like list of kings, as Kulamuwa names a line of predecessors, baldly dismissing each one (including his own father). The result is a narrative that is terse and lacking in details, which contrasts with Mesha's relatively detailed account. ${ }^{32}$ But the King of Sam'al's text represents an outline of the memorial inscription-format, and within this literary form is an idea of history that situates the ruler squarely within a narrative center. The point of the first section is to simply (and succinctly) bracket the past into generational categories, with Kulamuwa standing in the present as the king who acts. The second section ends the inscription with a set of curses directed against any successor ("sons") that might efface Kulamuwa's inscription.

The historical concerns in the memorial inscriptions of Mesha and Kulamuwa were about the past, present, and posterity of the king. The chronology here is tied to the king, although unlike the Samaria Ostraca this chronology does not use a dating formula that counts years. The ostraca were bureaucratic in function, whereas the memorial inscription's function was to offer a holistic view of the king's reign. For this reason, the genre shares some similarities with the dating system in Hazael's booty inscriptions. But unlike the booty inscriptions, memorial inscriptions collected multiple events (typically) and telescoped these events into a single narrative. Within the memorial inscription's narrative, historical time is collapsed into the metahistory of kingship, as the king places himself within the reoccurring cycle of kingship. Kings would establish linear continuity with the past through royal genealogies, but they would also assert the superior qualities of their time over-and-above the time of

30 Green (2010: 137) has referred to this as "paired memorial inscriptions," identifying it as a distinct feature of royal inscriptions from Sam'al (see also KAI 214, and 215).

31 Much of the difficulty has to do with the terms B'RRM and MŠKBM, which are not translated here. These terms are usually interpreted as social or ethnic categories (Landsberger 1948; Gibson 1982: 38; see Green 2010: 143 n. 31; and Schmitz 2013: 68-71), in light of the LuwianAramean background of Zincirli (Tropper 1993; Brown 2008: 339-56).

32 Although terse, the literary style and syntax is highly structured, which has led some to call it “narrative poetry” (Tropper 1993: 28-29; see Collins 1971: 183-88; cf. O’Connor 1977: 15-29) or describe it as having a "distinct poetic flavour" (Gibson 1982: 33). 
their predecessors (denigrating the past). Despite the ideal of dynastic continuity, memorial inscriptions would end with conditional curses placed upon progeny if they neglected the king's place in history. For this reason, memorial inscriptions rarely employ the sort of precise chronological markers that scholars often seek. ${ }^{33}$ Instead, chronology is assumed within its autobiographical form, as the king narrates his own history.

\section{Dedicatory inscriptions}

Unlike memorial inscriptions, dedicatory inscriptions are shorter and follow a more formulaic syntax (Herrmann 1958; Lehmann 2005; Sanders 2008: 98). The term "dedicatory" is actually imprecise, as this type of inscription has an application that is much more extensive. ${ }^{34}$ Similarly, the syntax is often called "votive,",35 although it serves different purposes in the various inscriptions. Regardless, the appearance of this type of text in monumental inscriptions usually serves a dedicatory function. The formula of these inscriptions is so regular that one can easily recognize them. Take the following (non-monumental) dedicatory inscription by Kulamuwa as an example: "Scepter" ${ }^{36}$ that was acquired (by) Kulamuwa, son of Ḥayya, for Rakib-El. May Rakib-El give him long life” (KAI 25). Written in Phoenician on a piece of golden foil, the text records Kulamuwa's actions (his acquisition) with regards the object (a scepter) on behalf of his dynastic god (Rakib-El). But given the formulaic nature of dedicatory inscriptions,

33 Contra Van Seter's statements regarding the sparse evidence for "annalistic traditions" in the Levant and lack of chronological structure in memorial inscriptions (1983: 195). While there are no existing examples of Iron Age annals or king-lists from the Levant, unlike Mesopotamian cuneiform tradition, Hazael's booty inscriptions (among other sources) suggest that chronology was systematized around kings in an annalistic manner. Furthermore, the Samaria Ostraca, while not annalistic, display methods of record keeping based upon the same principles seen in Near Eastern royal annals (Sanders 2008: 98-99).

34 This will become apparent in the discussion of 'Ahirom's sarcophagus (below).

35 The initial study of Julian Obermann (1948: 34-36) provided the groundwork for understanding this formulaic syntax. The opening formula is occasionally votive, as in the Dagan Steles from Ugarit (KTU 6.13-14); however, they can also be funerary (see Lewis 1989) as in the case of 'Ahirom's sarcophagus, as well as on later Phoenician remembrance-pillars from Cyprus. Aside from the Dagan steles, the syntactical form is also seen in an Ugaritic inscription from Sarepta (Greenstein 1976: 52-54), and it continues to be used in Aramaic well into later periods.

36 Following Galling (1950: 17-18). Among the different renderings, see also "amulet" suggested by Lemaire (1990: 326-27). 
should they be approached as historical writings? And, if so, how? The inscriptions of the Kings of Byblos provide data to address these questions.

The royal inscriptions from Byblos date from the tenth century (or lateeleventh) to the early ninth (Albright 1947; Rollston 2008: 57-93) and are written in a local form of Phoenician that is referred to in scholarship as "Old Byblian" (Garr 2004: 13; Gzella 2013: 170-98). Each of the five Old Byblian royal inscriptions follows the same formulaic pattern, although this pattern is inscribed on different objects. With one exception (the 'Ahirom sarcophagus), all of the inscriptions come from secondary contexts. As a result, it is difficult to date these inscriptions more precisely. Some chronological information can be inferred from the texts of Abiba'al and Eliba'al, which are written on Egyptian statues that belong to Shoshenq I (943-922 BCE) and Osorkon I (922-887 BCE), respectively. Thus the Egyptian artifacts provide a terminus a quo in the latetenth century, and the linguistic study of Old Byblian confirms this general dating. ${ }^{37}$ The genealogy found in Shipitba'al's identification, however, provides the framework that scholars use to chronologically organize the inscriptions (Albright 1947; Moscati 1968: 10-11; Vance 1994: 8-9). ${ }^{38}$ This data in fact represents a key element of historical thought; therefore Shipițba'al's dedicatory inscription provides a useful paradigm, even though it is chronologically later than the other four texts.

Wall that was built (by) Shipițba'al, king of Byblos, son of Eliba'al, king of Byblos, son of Yahumilk, king of Byblos, for the Lady of Byblos, his mistress. May the Lady of Byblos prolong the days of Shipițba'al, and his years, over Byblos. KAI 7

The Shipitba'al inscription replicates the style and form found on all of the other Old Byblian royal inscriptions. Moreover, the introduction follows the standard formula found on all so-called dedicatory inscriptions. Syntactically, the initial word is the object of dedication ("Wall" =OD), which is then followed by a relative clause that introduces the subject dedicating the object. In the relative clause, the verb ("built" $=\mathrm{V}$ ) attached to the relative particle ("that" $[z \bar{u}$ in Old Byblian] = R) varies depending on the object. But the verb here is always a

37 Holger Gzella (2013) suggests that the linguistic developments in Old Byblian began at the end of the second millennium BCE, continuing into the 10th and 9th centuries.

38 The Abiba'al inscription is the outlier (Vance 1994: 8-9), as it is fragmentary and does not contain genealogical information (nor is Abiba'al cross-referenced in the other inscriptions). Thus, it is unclear whether he is related to the dynasty of 'Ahirom or Yahumilk (Donner and Röllig 1968: 8; Gibson 1982: 20). The most common theories relate Abiba'al to Yahumilk, as either a brother or a son (and hence brother to Eliba'al). 
$3^{\text {rd }} \mathrm{m}$. singular preterit followed by a proper noun identifying the subject (Shipița'al=S). A preposition (always $l$-) marks the figure for whom the dedication is made ("the Lady of Byblos" =FD), before invoking a standardized blessing from this figure ("prolong the days of [Subject] and his years..." = B). ${ }^{39}$

\begin{tabular}{lllllll}
\hline Text & OD & R & V & S & FD & B \\
\hline KAI 5 & [Statue] & $z-$ & “brought” & Abiba‘al & Lady of Byblos & lengthy rule \\
KAl 4 & House & $z-$ & “built” & Yahumilk & [mult. deities] & lengthy rule \\
KAI 6 & Statue & $z-$ & “made” & Eliba‘al & Lady of Byblos & lengthy rule \\
KAI 7 & Wall & $z-$ & “built” & Shipitbaaal & Lady of Byblos & lengthy rule \\
KAl 25 & Scepter & $z-$ & “acquired” & Kulamuwa & Rākib-El & lengthy rule \\
\hline
\end{tabular}

The organized list of opening formulae (chronologically ordered, and including Kulamuwa) reveals several consistent features in content and form. Each of the Old Byblian inscriptions is dedicated to the Lady of Byblos ( $\left.b^{\circ} l \mathrm{gbl}\right),{ }^{40}$ which indicates that piety toward this goddess played an important role in kingship at Byblos (Moscati 1968: 25). In general, the historical time of the inscription is reflected in the brief description of the king's past action (as seen in the preterit verbal forms). But it is also ontologically linked to the blessings (another consistent feature), which express a desire for the king's extended rule. But beyond these formal conventions, another key feature is the royal genealogy built into the king's self-identification. The genealogy in Shipitba'al's inscription includes two generations, listing Shipitba'al's father (Eliba'al) and grandfather (Yahumilk). This information is useful for modern scholars, as it allows us to construct and arrange king-lists. But it also reflects an idea of history rooted in the king, where the past is organized into generations (following Ricoeur's use of the term [1984: 3; 2004: 155]). More specifically, the dedicatory inscription reflects the king's life and experience, described in the form's relative clause (the king's actions) as well as its blessings (the king's life). But in claiming royal pedigree, the king not only legitimizes himself, he also places his reign within the historical lineage of past kings.

Again, the idea of genealogy is encountered as a constituent feature of historical thought. A better term would be transgenerational, as each king

39 Obermann (1948: 35-36) outlined the first five features, and the final "blessing" was noted in subsequent studies (Lewis 1989; Lehmann 2005: 22).

40 There is no consensus opinion on the identity of this goddess (Moscati 1968; Clifford 1990; Bonnet 2010: 51-52; Zernecke 2013: 226-42), although she is mentioned in texts from Byblos beginning with the El-Amarna letters of Rib-Addi and continuing into the Persian Period. 
historically situates himself vis-à-vis past generations. In doing so each king claims kingship through patrilineal inheritance (Moscati 1968: 27). In these inscriptions, transgenerational time is part of the larger history of kingship, and the temporal concept's historical implications become clear when Shipitba'al's inscription is contrasted with that of his grandfather Yahumilk.

House that was built (by) Yahumilk, king of Byblos. He is the one that revived these fallen houses. May Ba'al-shamim and the Lady of Byblos, and the assembly of the gods of Byblos, the sacred ones, extend the days of Yahumilk and his years over Byblos, because he is a righteous king, and his rule is just before the sacred gods. KAI 4

Although Yahumilk's is the longest of the Old Byblian royal inscriptions, it is missing several features. To begin, the prepositional phrase that introduces the figure of dedication (FD) is absent. This is a minor detail, as a list of deities (including the Lady of Byblos) is evoked later in the blessings. More significantly, the inscription lacks any reference to royal genealogy. In the inscription's introduction, Yahumilk is identified simply as the King of Byblos, without patronym. Later in the text he is described further as a "just" and "righteous" ruler. The description of Yahumilk's virtues is an element that is not seen in any of the other Old Byblian inscriptions. ${ }^{41}$ This element, together with Yahumilk's lack of pedigree, suggests that he was a usurper (Moscati 1968; Gibson 1982: 17).

It is ironic that Yahumilk's heirs were able to participate in an aspect of kingship, royal genealogies, which otherwise excluded him. Denied this form of legitimacy, Yahumilk was forced to come up with alternative means of situating his reign within the larger history of kingship at Byblos. Thus, his inscription not only states his virtues (lines 6-7), but it also describes his pious actions in historical terms (line 2). Yahumilk does not identify himself with a patronymic, nor does he specifically name his predecessor. But he does insinuate that previous kings "did nothing” (to use Kulamuwa's parlance). This allusion, ${ }^{42}$ found in the second line ("[Yahumilk] is the one who revived these fallen houses" (KAI 4:2), is of course the same historiographical motif that appears in memorial texts (Drinkard 1989: 139; cf. Green 2010: 92-94): negative past $>$ positive present $>$ stable future. Unlike the literary form of memorial inscriptions, however, the perspective of Yahumilk's inscription is invoked through a blessing rather than a curse.

41 The motif, however, is found on other inscriptions, including the Persian Period memorial stele of Yehaumilk (Moscati 1968: 27).

42 Literarily, the syntactical structure of this clause re-emphasizes Yahumilk's actions (Schade 2006: 121-24). 
Yahumilk's use of the blessing formula reveals an important historical aspect of the dedicatory form. The benediction's stability is tied to the present realities of Yahumilk's reign ("extend... the days of Yahumilk and his years over Byblos"), rather than the future of his dynasty. The latter motif occurs in the imprecations at the end of memorial inscriptions, where the curses are generally directed at sons (see Kulamuwa, above). The curses are due to the retrospective nature of memorial inscriptions, which contrasts with the function of dedicatory inscriptions. The dedicatory texts from Byblos, and elsewhere, create a sense of immediacy through the deixis of the opening formula. ${ }^{43}$ This may explain why no other chronological data is specified (i.e. the month or year of the dedication). The dedicated object is an enduring and ongoing reminder of the king's actions, perpetuating his royal claims.

The basic form of the dedicatory inscription does not appear to require distinct chronological markers. Yet the concept of transgenerational time plays an important role, even though it is only implicit in the genealogies found in each king's identification (Yahumilk notwithstanding). The role of generational time is apparent in the one Old Byblian royal inscription that involves curses, 'Ahirom's sarcophagus.

Sarcophagus that was made (by) 'Ittoba'al, son of 'Ahirom, the king of Byblos, for 'Ahirom, his father, when he placed him in the eternal place. And if a king among kings or a governor among governors or the commander of an army should rise up against Byblos and uncover this sarcophagus, may the scepter of his rule be uprooted, may the throne of his kingship be overturned, and may peace depart from Byblos! And, as for him, may his inscription be effaced... ${ }^{44}$ KAI 1

The 'Ahirom sarcophagus is the only Old Byblian royal inscription to come from a known context, as it was discovered in a tomb (Lehmann 2005; Niehr 2010: 230-31). Like the other texts, 'Ahirom's sarcophagus inscription follows the so-called votive syntax. Unlike the other texts, however, this inscription is not dedicatory but funerary. The opening formula deictically marks the sarcophagus and identifies 'Ittoba'al as the text's subject (the person who "made" the object). But the differences that follow are at once subtle (the formula's indirect object) and stark (the inclusion of curses).

The inscription indicates that the sarcophagus belongs to 'Ahirom, as his name is grammatically marked by the $l$ - preposition: Ittoba'al, his son, made this

43 See, similarly, Sander's (2009: 98) discussion of the deictic force of this syntax: "(This is the) house built by..."

44 The last few words of the final line are ambiguous (lpp.šbl) and there is little agreement over their interpretation, thus they are not translated here. 
sarcophagus for 'Ahirom. The use of the preposition otherwise follows the standard form seen in the other Old Byblian royal inscriptions. Yet the subtle difference is that in those cases the preposition marks the Lady of Byblos, that is, the goddess for whom the king acts. The reciprocal relationship between the goddess and her king is invoked at the end of each dedicatory inscription through jussive verbs (simple imperfects) that request her blessings. This relationship does not exist in the inscription on 'Ahirom's sarcophagus, which ends with general curses against anyone who disturbs the tomb. In fact, 'Ahirom's role in the text is entirely passive; he did not serve as a source for blessings or curses. Instead, the curses are reflexive, expressed through rare Gt-verbal forms. ${ }^{45}$ Furthermore, the curses are primarily directed at symbols of royal power ("may the scepter of his rule be uprooted [thtsp], may the throne of his kingship be overturned [thtpk]"). Thus, the curses are not concerned with postmortem status, as was the case with the later Sidonian royal sarcophagi of Tabnit and Eshmunazor. The curses reflect the fact that 'Ittoba'al's text (inscribed upon his father's sarcophagus) was not concerned with securing the blessings of a deity. Rather, the purpose of the text was to establish a link with kingship.

The syntactical relationship between the inscribed object (the sarcophagus), Ittoba'al, and his deceased father 'Ahirom, is dependent upon the ideal of dynastic succession. As a defunct king, 'Ahirom was powerless to protect his tomb (or bless his son with long life), yet he was able to confer kingship through patrilineal succession. ${ }^{46}$ Ittoba'al was able to claim this kingship by performing his filial duty in burying his father. The sarcophagus (with 'Ahirom's body inside) stands as a symbol of Ittoba'al's actions. Any interference with this object would have represented a political threat to Ittoba'al's kingship (Suriano 2010: 106-07), therefore the curse is directed against kings, governors, and military leaders ("commanders"). Furthermore, the curse specifically targets political symbols (scepter and throne). In some ways the inscription's curse can be related to the blessings found in the other dedicatory inscriptions. The curses in 'Ahirom's sarcophagus were meant to guard an institution that was claimed by Ittoba'al through his dead father. In this manner, the curses were immanently

45 See the description of this form in the various grammars (Harris 1936; Friedrich and Röllig 1999; Krahmalkov 2001: 157). While the semantics of the $t$-infix should not be limited to reflexivity, this verb form only occurs in Phoenician here, within a literary context of imprecations.

46 The inscription, however, never refers to 'Ahirom as the "King of Byblos." This omission raises questions whether he was ever king (Lehmann 2005: 26), although if 'Ittoba'al was a usurper, a royal burial for his father might have had the same effect. 
related to the new king's political status, which is similar to the benedictions (of the dedicatory inscriptions) requesting a lengthy reign over Byblos.

The text of 'Ittoba'al, however, is more overtly transgenerational than the dedicatory inscriptions. Its purpose relates directly to the ideal of dynastic succession. This ideal is reified through syntax as it records an action that is part of the patrilineal transfer of authority: the burial of the dead king. Parallel to the reciprocal relationship of king and goddess, seen in the dedicatory inscriptions, the syntax in the sarcophagus inscription establishes a transgenerational relationship between 'Ittoba'al and 'Ahirom. In the sarcophagus text, the organization of time and history into generations follows the transitional patterns of death and new life. The burial of the past king of Byblos points forward to the present kingship of the text's subject, 'Ittoba'al. ${ }^{47}$ But the stark imagery of the curses reveals the violence necessary to protect and maintain kingship, even in cases where it could be claimed through legitimate means.

The comparison of 'Ahirom's sarcophagus inscription with the dedicatory inscriptions from Byblos draws to the forefront basic questions regarding the meaning of royal inscriptions and their utility as historical sources. Certainly the dedications made by the kings of Byblos represent the records of events that occurred in history. But the problem with the so-called dedicatory form in general, and the Old Byblian royal inscriptions in particular, is their lack of chronological benchmarks (aside from the genealogical data). The question of chronology should be set aside, however, given the symbolic nature of the inscription. The symbolic significance of the inscribed artifact is in the way it fronts the dedicated object; the first word of the formula is the inscribed artifact (i.e. "Wall... [KAI 7:1]). At the same time, the formula highlights the subject responsible for the dedication. Thus, the inscribed artifact acts as a historical transponder, continually transmitting the message it received. In this way, the dedicatory inscription served as an enduring symbol of the respective subject's kingship.

The symbolic nature of these texts, the Iron IIA royal inscriptions of Byblos, itself is of historical significance. The dedicatory inscriptions were typically monumental and hence public, yet 'Ahirom's sarcophagus would have been otherwise inaccessible once it was sealed inside his tomb. ${ }^{48}$ The object that 'Ittoba'al used to bury his father, however, was a reused sarcophagus that originated in the Late Bronze Age (Rehm 2004). ${ }^{49}$ 'Ittoba'al apparently inscribed the text, which was dedicated to his father 'Ahirom, over a previous Proto-

47 See similarly in the Book of Kings (Suriano 2010: 176).

48 The entrance to 'Ahirom's burial chamber bore an inscription warning all who enter (KAI 2).

49 The sarcophagus is generally dated to the 13th (Rehm 2004) or 12th centuries (Markoe 2000: 144-45), although Edith Porada (1973: 354-72) had argued that the sarcophagus and the 
Byblian syllabary inscription (so-called "pseudo-hieroglyphic"; Martin 1961; Gibson 1982: 12-13). ${ }^{50}$ There is profound irony in this fact: 'Ittoba'al, in his curse, warns against the very action he had done himself (Vance 1994: 7-8). The sarcophagus represented the kingship that 'Ittoba'al claimed through his father, a claim that he performed through funerary rituals. The violation of 'Ahirom's tomb meant the disruption of the kingship that he passed down through his heirs. 'Ittoba'al's actions were not unique, however, as Yahumilk had also effaced an earlier Proto-Byblian syllabary inscription, superimposing his own dedicatory text on a reworked stone slab (Gibson 1982: 17). As already noted, the dedicatory inscriptions of Abiba'al and Eliba'al are both written on Egyptian statues that belonged to pharaohs of the 22nd dynasty. The inscribed objects themselves are part of the metahistory of kingship at Byblos, and in each instance the king claims an object (through dedication or other ritual means) and re-inscribes his name upon it. The actions of these kings, however, tacitly deny the past (whether it is Egyptian hegemony or Proto-Byblian traditions), ${ }^{51}$ in order to emphasize their own place in history.

\section{Conclusion}

This essay sought to develop a hermeneutical approach to royal writings using the inscriptions of Mesha, Kulamuwa, and the Old Byblian kings as test cases. The purpose of this reading exercise was to elucidate historical thought in royal inscriptions at the level of narrative. Although their styles differ, both memorial and dedicatory inscriptions structure historical thought around the person of the king. In memorial inscriptions, the king narrates historical time, but in dedicatory inscriptions the king participates in the larger metahistory of kingship. In each, the concepts of metahistory and historical time intersect, and it is in this

inscription both dated to ca. 1000 BCE. The tomb system itself was part of a series of subterranean hewn-tombs that originated in the Middle Bronze Age, though Tomb V (where 'Ahirom's sarcophagus was found) may date to the Late Bronze Age (Porada 1973; Rehm 2004: $17-19)$.

50 Although there is common agreement that the inscription is secondary (Lundberg 2004; Lehmann 2005: 19), Reinhard Lehmann (2008: 122) has cast doubt on the presence of an earlier Proto-Byblian text based on his work directly with the sarcophagus.

51 The history of Egyptian hegemony over Byblos is too extensive to cover in this article. The Egyptian story of Wenamun, however, reflects the transitional situation at the Late Bronze Age, as Byblos began to remove the yoke of Egyptian control. See also Herrmann (1958: 28-31) and Moscati (1968: 11) on the use of the term "King of Byblos" ( $m l k g b l)$ in the Old Byblian royal inscriptions. 
moment that it becomes possible to view the inscription as the element that made up the king's reality (to paraphrase Liverani). If we move away from looking at royal inscriptions as messages about the past, and approach them as forms of past media, it becomes possible to recognize the historical consciousness of the respective king that is deeply embedded within each artifact.

\section{References}

Albright, William F. 1947. The Phoenician Inscriptions of the Tenth Century B.c. from Byblus. JAOS 67: 153-69.

Benveniste, Émile. 1965. Language and Human Experience. Diogenes 13: 1-12.

Bonnet, Corinne. 2010. Die Religion der Phönizier und Punier. Pp. 13-185 in Religionen in der Umwelt des Alten Testaments II: Phönizier, Punier, Aramäer, eds. G. Bitter, E. Dassmann, C. Frevel, H.-J. Klauck, and H. Vorgrimler. Stuttgart: W. Kohlhammer.

Bron, François, and André Lemaire. 1989. Les inscriptions araméenes de Hazaël. RA 83: 35-44.

Brown, Brian. 2008. The Kilamuwa Relief: Ethnicity, Class and Power in Iron Age North Syria. Pp. 339-55 in Proceedings of the 5th International Congress on the Archaeology of the Ancient near East: Madrid, April 3-8, 2006, eds. J. Córdoba, M. Molist, C. Pérez, I. Rubio, and S. Martínez. Madrid: Ediciones Universidad Autónoma de Madrid: Centro Superior de Estudios sobre el Oriente Próximo y Egipto.

Çambel, Halet. 1999. Corpus of Hieroglyphic Luwian Inscriptions. Studies in Indo-European Language and Culture. Vol. I (Karatepe-Aslantaş). Berlin: Walter de Gruyter.

Charbonnet, André. 1986. Le dieu aux lions d'Eretrie. AION 8: 117-73, Pls. 133-41.

Clifford, Richard J. 1990. Phoenician Religion. BASOR 279: 55-64.

Cogan, Mordechai. 2001. 1 Kings: A New Translation with Introduction and Commentary. Anchor Bible, 10. New York: Doubleday.

Collins, Terence. 1971. The Kilamuwa Inscription-a Phoenician Poem. WdO 6: 183-88.

Dearman, J. Andrew. 1989. Historical Reconstruction and the Mesha Inscription. Pp. 155-210 in Studies in the Mesha Inscription and Moab, ed. J. Andrew Dearman. Archaeology and Biblical Studies, 2. Atlanta, GA: Scholars Press.

Dion, P.-E. 1997. Les Araméens à l'âge du Fer, Études Bibliques [Ns] 34. Paris: J. Gabalda.

Dobbs-Allsopp, F. W., J. J. M. Roberts, C. L. Seow, and R. E. Whitaker. 2004. Hebrew Inscriptions: Texts from the Biblical Period of the Monarchy with Concordance. New Haven, CT: Yale University Press.

Donner, H., and W. Röllig. 1966-69. Kanaanäische und aramäische Inschriften. Bd. 1 (Texte, 1966), Bd. II (Kommentar, 1968), Bd. III (Glossare und Indizes, Tafeln, 1969). Wiesbaden: Otto Harrassowitz.

Drinkard, Joel. F. 1989. The Literary Genre of the Mesha Inscription. Pp. 131-54 in Studies in the Mesha Inscription and Moab, ed. J. Andrew Dearman. Archaeology and Biblical Studies, 2. Atlanta, GA: Scholars Press.

Eph'al, Israel, an. 1989. Hazael's Booty Inscriptions. IEJ 39: 193-200.

Fales, Frederick M. 1979. Kilamuwa and the Foreign Kings: Propaganda vs. Power. Die Welt des Orients 10: 6-22. 
Friedrich, Johannes, and Wolfgang Röllig. 1999. Phönizisch-Punische Grammatik, 3. Aufl./ ed. Maria G. Amadasi Guzzo, Analecta Orientalia 55. Rome: Pontificio Istituto biblico.

Gadamer, Hans G. 1975. Truth and Method. A Continuum Book. New York: Seabury Press.

Galil, Gershon. 1996. The Chronology of the Kings of Israel and Judah. SHCANE 9. New York: Brill.

Galling, Kurt. 1950. The Scepter of Wisdom: A Note on the Gold Sheath of Zendjirli and Ecclesiastes 12:11. BASOR 119: 15-18.

Garr, W. Randall. 2004. Dialect Geography of Syria-Palestine, 1000-586 B.C.E. Winona Lake, IN: Eisenbrauns.

Gibson, J. C. L. 1982 Textbook of Syrian Semitic Inscriptions. Vol. 3. Phoenician inscriptions, including inscriptions in the mixed dialect of Arslan Tash. Oxford: Clarendon Press.

Grabbe, Lester L. 2004. A History of the Jews and Judaism in the Second Temple Period. Vol. 2. The early Hellenistic period (335-175 BCE), Library of Second Temple Studies. London: T\&T Clark International.

Grabbe, Lester L. 2007. Ancient Israel: What Do We Know and How Do We Know It? London: T \& T Clark. Green, Douglas J. 2010. "I Undertook Great Works." The Ideology of Domestic Achievements in West Semitic Royal Inscriptions. FAT 2, 41. Tübingen: Mohr Siebeck.

Greenstein, Edward L. 1976. A Phoenician Inscription in Ugaritic Script? JANES 8: 49-57.

Greenstein, Edward L. and David Marcus. 1976. The Akkadian Inscription of Idrimi. JANES 8: 59-96. Gzella, Holger. 2013. The Linguistic Position of Old Byblian. Pp. 170-98 in Linguistics Studies in Phoenician in Memory of J. Brian Peckham, eds. R. D. Holmstedt and A. Schade. Winona Lake, IN: Eisenbrauns.

Hafthorsson, Sigurdur. 2006. A Passing Power: An Examination of the Sources for the History of Aram-Damascus in the Second Half of the Ninth Century B.C., Coniectanea Biblica Old Testament Series. Stockholm: Almqvist \& Wiksell International.

Harrak, Amir. 1992. Des noms d'année en araméen? WdO 23: 8-74.

Harris, Zellig. S. 1936. A Grammar of the Phoenician Language. AOS, 8. New Haven, CT: American Oriental Society.

Harrison, Timothy P. 2001. Tell Ta'yinat and the Kingdom of Unqi. Pp. 115-32 in The World of the Aramaeans II, eds. P. M. M. Daviau, J. W. Wevers, and M. Weigl. Sheffield: Sheffield Academic Publishers.

Heidegger, Martin. 1962. Being and Time. Trans. John Macquarrie \& Edward Robinson. New York: Harper.

Herrmann, Wolfram. 1958. Der historische Ertrag der altbyblischen Königsinschriften. MIO 6: 14-32.

Ishida, Tomoo. 1977. The Royal Dynasties in Ancient Israel: A Study on the Formation and Development of Royal-Dynastic Ideology, ed. G. Fohrer. Beiheft zur Zeitschrift für die alttestamentliche Wissenschaft, 142. Berlin: W. de Gruyter.

Jauss, Hans R. 1970. Literary History as a Challenge to Literary Theory. New Literary History 2: 7-37.

Kantor, Helene J. 1962. Oriental Institute Museum Notes, No. 13: A Bronze Plaque with Relief Decorations from Tell Tainat. JNES 21: 93-117.

Kaufman, Ivan T. 1966. The Samaria Ostraca: A Study in Ancient Hebrew Paleaography. Th.D. Dissertation, Harvard University.

Kaufman, Ivan T. 1982. The Samaria Ostraca: An Early Witness to Hebrew Writing. BA 45: 229-39.

Koselleck, Reinhart. 1985. Futures Past: On the Semantics of Historical Time, trans. Keith Tribe. Studies in Contemporary German Social Thought. Cambridge, MA: MIT Press. 
Koselleck, Reinhart. 1989. Linguistic Change and the History of Events. Journal of Modern History 61: 649-66.

Krahmalkov, Charles R. 2001. A Phoenician-Punic Grammar. HdO I: ANEME, 54. Leiden: Brill. Kyrieleis, Helmut, and Wolfram Röllig. 1988. Ein altorientalischer Pferdeschmuck aus dem Heraion von Samos. $A M$ 103: 37-75, Pls. 39-15.

Landsberger, Benno. 1948. Sam'al: Karatepe. Türk Tarih Kurumu: Ankara.Lehmann.

Lehmann, Reinhard G. 2005. Dynastensarkophage mit szenischen Reliefs aus Byblos und Zypern: Teil 1.2: Die Inschrift(en) des Ahirom-Sarkophags und die Schachtinschrift des Grabes $V$ in Jbeil (Byblos), Forschungen zur phönizisch-punischen und zyprischen Plastik. Mainz: Philipp von Zabern.

Lehmann, Reinhard G. 2008. "Calligraphy and Craftsmanship in the Ahīrōm.” Maarav 15: 119-64.

Lemaire, André. 1977. Inscriptions hébraïques. Littératures anciennes du Proche-Orient, 9. Tome I: Les Ostraca. Paris: Cerf.

Lemaire, André. 1990. SMR dans la petite inscription de Kilamuwa (Zencirli). Syria 67: 323-27. Lemaire, André. 1998. Formules de datation en Palestine au premier millénaire avan J.-C. Pp. 53-82 in Proche-Orient ancien: temps vécu, temps pensé, eds. F. Briquel-Chatonnet and $\mathrm{H}$. Lozachmeur. Paris: Jean Maisonneuve.

Lemaire, André. 2007. The Mesha Stele and the Omri Dynasty. Pp. 135-44 in Ahab Agonistes: The Rise and Fall of the Omri Dynasty, ed. L. L. Grabbe. London: T\&T Clark.

Lewis, Theodore J. 1989. Cults of the Dead in Ancient Israel and Ugarit. HSM 39. Atlanta, GA: Scholars Press.

Lipiński, E. 2000. The Arameans: Their Ancient History, Culture, Religion. OLA. Sterling, VA: Peeters.

Liverani, Mario. 1973. Memorandum on the Approach to Historiographic Texts. Or 42: 178-94. Lundberg, Marilyn J. 2004. Editor's Notes: The Ahiram Inscription. Maarav 11: 81-93.

Markoe, Glenn. 2000. Phoenicians. Peoples of the Past. Berkeley, CA: University of California Press.

Martin, Malachi. 1961. A Preliminary Report after Re-Examination of the Byblian Inscriptions. Or 30: 46-78.

Michalowski, Piotr. 1983. History as Charter: Some Observations on the Sumerian King List. JAOS 103: 237-48.

Miller, J. Maxwell. 1974. The Moabite Stone as a Memorial Stela. PEQ 106: 9-18.

Miller, J. M. 1989. Moab and the Moabites. Pp. 1-40 in Studies in the Mesha Inscription and Moab, ed. J. A. Dearman. Archaeology and Biblical Studies, 2. Atlanta, Ga.: Scholars Press.

Moscati, Sabatino. 1968. The World of the Phoenicians. Praeger History of Civilization. New York: Praeger.

Na'aman, Nadav. 2000. Three Notes on the Aramaic Inscription from Tel Dan. IEJ 50: 92-104.

Na'aman, Nadav. 2007. Royal Inscription Versus Prophetic Story: Mesha's Rebellion According to Biblical and Moabite Historiography. Pp. 145-83 in Ahab Agonistes: The Rise and Fall of the Omri Dynasty, ed. L. L. Grabbe. London: T\&T Clark.

Nam, Roger. 2012. Power Relations in the Samaria Ostraca. PEQ 144: 155-63.

Niehr, Herbert. 2010. Religion in Den Königreichen Der Aramäer Syriens. Pp. 189-324 in Religionen in der Umwelt des Alten Testaments II: Phönizier, Punier, Aramäer. Stuttgart: W. Kohlhammer.

Niehr, Herbert. 2011. König Hazael von Damaskus im Licht neuer Funde und Interpretationen. Pp. 339-56 in "Ich werde meinen Bund mit euch niemals brechen!" (Ri 2,1): Festschrift Für 
Walter Gross zum 70. Geburtstag, eds. Erasmus Gass and H.-J. Stipp. Herders Biblische Studien, 62. Freiburg im Breisgau: Herder.

Niemann, Hermann M. 2008. A New Look at the Samaria Ostraca: The King-Clan Relationship. TA 35: 249-66.

O'Connor, Michael. 1977. The Rhetoric of the Kilamuwa Inscription. BASOR 226: 15-29.

Obermann, Julian. 1948. Votive Inscriptions from Ras Shamra. JAOS 61: 31-45.

Parker, Simon B. 1999. The Composition and Sources of Some Northwest Semitic Royal Inscriptions. SEL 16: 49-62.

Parker, Simon B. 2000. Did the Authors of the Books of Kings Make Use of Royal Inscriptions? VT 50: 357-78.

Payne, Annick. 2012. Iron Age Hieroglyphic Luwian Inscriptions, Writings from the Ancient World. Atlanta: Society of Biblical Literature.

Porada, Edith. 1973. Notes on the Sarcophagus of Ahiram. JANES 5: 354-72.

Rainey, Anson F. 1979. The Sitz Im Leben of the Samaria Ostraca. TA 6: 91-94.

Rehm, Ellen. 2004. Dynastensarkophage mit szenischen Reliefs aus Byblos und Zypern: Dynastensarkophage: Teil 1.1. Forschungen zur phönizisch-punischen und zyprischen Plastik. Mainz: Philipp von Zabern.

Reisner, George Andrew, Clarence Stanley Fisher, and David G. Lyon. 1924. Harvard Excavations at Samaria, 1908-1910. Harvard Semitic Series. Vol. 1. Text. Cambridge: Harvard University.

Ricoeur, Paul. 1980. Narrative Time. Critical Inquiry 7: 169-90.

Ricoeur, Paul. 1984. Time and Narrative. 3 Vols. Chicago: University of Chicago Press.

Ricoeur, Paul. 2004. Memory, History, Forgetting. Chicago: University of Chicago Press.

Röllig, Wolfram. 1999. The Phoenician Inscriptions. Pp. 50-81 in Corpus of Hieroglyphic Luwian Inscriptions, ed. H. Çambel, Studies in Indo-European Language and Culture. Vol. I (Karatepe-Aslantaş). Berlin: Walter de Gruyter.

Rollston, Christopher A. 2008. The Dating of the Early Royal Byblian Phoenician Inscriptions: A Response to Benjamin Sass. Maarav 15: 57-93.

Rollston, Christopher A. 2010. Writing and Literacy in the World of Ancient Israel: Epigraphic Evidence from the Iron Age. Atlanta, GA: Society of Biblical Literature.

Routledge, Bruce E. 2004. Moab in the Iron Age: Hegemony, Polity, Archaeology. Archaeology, Culture, and Society. Philadelphia, PA: University of Pennsylvania Press.

Sanders, Seth L. 2008. Writing and Early Iron Age Israel: Before National Scripts, Beyond Nations and States. Pp. 97-112 in Literate Culture and Tenth-Century Canaan: The Tel Zayit Abecedary in Context, eds. R. E. Tappy and P. K. McCarter. Winona Lake, IN: Eisenbrauns.

Schade, Aaron. 2006. The Syntax and Literary Structure of the Phoenician Inscription of Yehimilk. Maarav 12: 121-24.

Schloen, J. David. 2001. The House of the Father as Fact and Symbol: Patrimonialism in Ugarit and the Ancient near East. Studies in the Archaeology and History of the Levant, 2. Winona Lake, IN: Eisenbrauns.

Schmitz, Philip C. 2013. The Phoenician Words MŠKB and 'RR in the Royal Inscriptions of Kulamuwa (KAI 24:14-15) and the Body Language of Peripheral Politics. Pp. 68-83 in Linguistics Studies in Phoenician in Memory of J. Brian Peckham, eds. R. D. Holmstedt and A. Schade. Winona Lake, IN: Eisenbrauns.

Suriano, Matthew J. 2007a. A Fresh Reading for 'Aged Wine' in the Samaria Ostraca. PEQ 139: 27-33. 
Suriano, Matthew J. 2007b. The Apology of Hazael: A Literary and Historical Analysis of the Tel Dan Inscription. JNES 66: 163-76.

Suriano, Matthew J. 2010. The Politics of Dead Kings: Dynastic Ancestors in the Book of Kings and Ancient Israel. FAT II, 48. Tübingen: Mohr Siebeck.

Suriano, M. J. 2009. Dynasty Building at Ugarit: The Ritual and Political Context of KTU 1.161. Aula orientalis 27: 105-23.

Tadmor, Hayim. 1979. The Chronology of the First Temple Period. Pp. 44-60, 318-20 in The World History of the Jewish People, ed. A. Malamat. Jerusalem: Massada.

Tappy, Ron E. 2001. The Archaeology of Israelite Samaria, Volume II: The Eighth Century BCE. HSS, 50. Atlanta, GA: Scholars Press.

Tropper, Josef. 1993. Die Inschriften Von Zincirli. Münster: UGARIT-Verlag.

Van Seters, John. 1983. In Search of History: Historiography in the Ancient World and the Origins of Biblical History. New Haven, CT: Yale University Press.

Vance, Donald R. 1994. Literary Sources for the History of Palestine and Syria: The Phoenician Inscriptions. BA 57: 2-19.

White, Hayden V. 1973. Metahistory: The Historical Imagination in Nineteenth-Century Europe. Baltimore, MD: Johns Hopkins University Press.

Younger, K. Lawson. 1990. Ancient Conquest Accounts: A Study in Ancient near Eastern and Biblical History Writing, JSOTSupp, 98. Sheffield: JSOT Press.

Zernecke, Anna. 2013. The Lady of Titles: The Lady of Byblos and the Search for "True Name". WdO 43: 226-42.

Note: This article was produced through the generous support of several institutions. I would like to thank the Joseph and Rebecca Meyerhoff Center for Jewish Studies and the College of Arts and Humanities at the University of Maryland for making possible my research leave in the spring of 2014. The Department of Near Eastern Studies at Johns Hopkins University generously provided me with fellow-by-courtesy status, allowing me to conduct research at their facilities during this time. Although I alone am responsible for the contents within, the article benefited from the comments of Benjamin Suriano, Kyle Keimer, Jacqueline Vayntrub, Chris McKinny, and an anonymous reviewer. The study is dedicated to my friend and mentor William Schniedewind. 